\title{
EFFECT OF USING TOMATO POMACE POWDER AS A BY-PRODUCT FROM FOOD FACTORIES ON SENSORIAL, RHEOLOGICAL, CHEMICAL AND MICROBIOLOGICAL PROPERTIES OF PIZZA ADOUGH.
}

\author{
By \\ Ramadan, Afaf-Haniem .M \\ Nagib, R.M. \\ Home Economics Dept., Faculty of \\ Specific Education, Mansoura \\ Univ., Egypt.

$$
\text { El far, M.M. }
$$ \\ Home Economics Dept., Faculty of \\ Specific Education, Mansoura \\ Univ., Egypt. \\ Home Economics Dept., Faculty of Specific Education, \\ Mansoura Univ., Egypt.
}

\section{Research Gournal Specific Fducation}

Faculty of Specific Education

gYansoura University

ISSUE NO. 36, OCTOBER. 2014

$$
\begin{aligned}
& \text { مجلة بحوث التربية النوعية - جامعة المنصورة } \\
& \text { العدد السادس والثلاثون - اكتوبر عا.بمانج }
\end{aligned}
$$




\title{
EFFECT OF USING TOMATO POMACE POWDER AS A BY-PRODUCT FROM FOOD FACTORIES ON SENSORIAL, RHEOLOGICAL, CHEMICAL AND MICROBIOLOGICAL PROPERTIES OF PIZZA ADOUGH.
}

\author{
Ramadan, Afaf-Haniem .M*
}

Nagib, R.M.

El far, M.M.

\section{Abstract}

The objective of this study feasibility of using tomato pomace powder (TPP) as a by-product from food industry to produce pizza dough were utilized in substituting part of wheat flour (72\% extra.) at two levels (7 and $12 \%)$.At the first, organoleptic properties of different pizza samples were evaluated, then chemical, rheological, physicochemical and total bacterial and fungi count were studied. The results indicated that tomato pomace powder was extremely in protein, ash, dietary fiber as compared with wheat flour (72\% extra).Also; tomato pomace powder has the highest percentage of lycopene $(9.17 \mathrm{mg} / 100 \mathrm{~g})$ and Vitamin C (44.6mg/100g). Sensorial evaluation showed that there were significant differences between pizza samples containing tomato pomace powder substitution with 7 and 12\% compared with control pizza (100\%wheat flour $72 \%$ extra.).However pizza sample which prepared substation with $12 \%$ tomato pomace powder was significantly higher than control sample which prepared with $100 \%$ wheat flour (72\% extra) at all sensory characteristics except taste property. The rheological characteristics for pizza dough formulae were studied. Water absorption increased significantly with increasing tomato pomace powder (TPP) from 7 to $12 \%$. Dough stability and Elasticity were increased whereas extensibility values decreased. Also, firmness were increased significantly with increasing (TPP).pizza prepared from $12 \%$ tomato pomace powder had a higher ratio of dietary fiber, protein and ash. The results indicated that addition of tomato pomace powder as a by-product from food factories up to $12 \%$ was feasible to produce sensorial acceptable pizza. In generally, it can be stated that enrichment of pizza with tomato pomace powder is advantageous due to the increased nutritional value, as tomato pomace powder is rich source of dietary fiber, vitamin c, lycopene and B-carotene.

Keywords: pizza, food processing by-product, tomato pomace, sensorial, chemical and rheological characteristics, microbiological.

Home Economics Dept., Faculty of Specific Education, Mansoura Univ., Egypt. 
Effect of using tomato pomace powder as a By-product from food factories

\section{Introduction}

Nowadays, there is a considerable interest in studying the feasibility of using by-products from food processing plants as raw materials for production of dietary fiber powder since these wastes are inexpensive and highly abundant. Fruits and vegetables wastes or residues are among the most promising by-products with high dietary fiber content, and possess a good balance between soluble dietary fiber (SDF) and insoluble dietary fiber (IDF).By-products for further exploitation on the production of food additives or supplements with high nutritional value have gained increasing interest because these are high-value products and their recovery may be economically attractive. It is well known that by-products represent an important source of sugars, minerals, organic acid, dietary fiber and phenolics which have a wide range of action which includes antitumoral, antiviral, antibacterial, cardio protective and ant mutagenic activities Sonja Djilas Jasna et al., (2009).Tomato (Lycopersicun esculentum) is one of the most widely cultivated vegetable crops in Iran Rezaeipour et al., (2008). Tomato pomace is a by-product obtains from the processing of tomatoes for concentrated paste, juice, sauce and ketchup and contains skin and seeds. Tomato pomace is a fibrous material and small proportion is dried and use as an animal feed Haddadin et al., (2001). Carlson et al., (1981) showed that the addition of tomato seed to wheat flour bread had a positive effect on loaf volume and improved the overall protein quality of the bread. The supplementation at10 and 20\%replacement levels increased lysine by 40.2 and $69.0 \%$ respectively. The high fiber content of dried tomato pomace indicates that it can be used in poultry diets at low inclusion rates as an alternative to cereal byproducts Dotas et al., (1999). Researchers are constantly searching for ways to improve the worldwide use of tomato residues by including them in poultry feed Assi and King, (2007); Squires et al., (1992). One approach to increase the rate of these ingredients in poultry diets is possible by hydrolyzing the crude fiber into digestible saccharides Haddadin et al., (2001).It is well documented that foods can be made healthier by using ingredients or amounts of ingredients with less calories, sodium, and saturated fat without the consumer knowing. This is known as 
the „stealth health " approach Tribole, (1999); Wagner et al., (2007); Lone et al., (2009). For example, in the study by Montesano et al., (2006), the trained panelists could not detect a difference between the $100 \%$ highgluten flour and the 100\% high-gluten plus flax crust when the pizza samples were eaten with the toppings. However, little is known about the effects of the stealth health approach on consumer acceptance. Considering the high consumption of pizza, the current nutrient content in pizza and the issues of chronic disease in this country, understanding the consumer acceptance of "healthier" pizza may have great significance.

\section{Materials and methods}

\section{Materials}

Wheat flour: (Triticum aestivum) (72\% extra), sugar, yeast and salt were purchased from local market, El- Mansoura city, Egypt.

Tomato pomace (Lycopersicum esculentum): Was obtained from Egyptian Canning Company (BEST), Meniat Samannud, Aga, Dakhleia Governorate, Egypt.While margarine was purchased from Misr Oil and Soap Company, El-Mansoura city, Egypt.

The Growth media: Dextrose, Peptone, potassium dihydrogen phosphate, Magnesium sulfate, Rose Bengal, Nutrient agar, Streptomycin solution and Beef extract were purchased from El-Gomhoria company for Trading in Medicines, Chemicals and Medical Supplies, Mansoura city, Egypt.

\section{Methods}

Preparation of tomato pomace powder: Tomato pomace by-product was dried in electric drier oven at $50 \mathrm{C}^{\mathrm{o}}$ for 5:6 hrs. until the moisture content ranged from (7to10\%). Then ground separately using a Maxy hermetic Mill Grinder, patent N:53985B, Italy to pass through 60 mesh sieve. The powder samples were packaged in polyethylene bags and stored in cool at 4-7 $\mathrm{C}^{\mathbf{o}}$ until using and analysis according to Hegazy and Ibrahium, (2009).

\section{Pizzas dough manufacture:}

Pizza dough formulae were prepared according to Clarke and Farrell 
(2000) and Ingredients were in Table (1).

Table (1): Ingredients used in pizza dough formulae\% .

\begin{tabular}{||c||c|c|c||}
\hline \multicolumn{1}{|c||}{ Samples } & PC & PS 1 & PS 2 \\
\hline \hline Flour & $100 \mathrm{~g}$ & $93 \mathrm{~g}$ & $88 \mathrm{~g}$ \\
\hline \hline Tomato pomace & - & $7 \mathrm{~g}$ & $12 \mathrm{~g}$ \\
\hline \hline Margarine & $14 \mathrm{~g}$ & $14 \mathrm{~g}$ & $14 \mathrm{~g}$ \\
\hline Sugar & $1 \mathrm{~g}$ & $1 \mathrm{~g}$ & $1 \mathrm{~g}$ \\
\hline Yeast & $2 \mathrm{~g}$ & $2 \mathrm{~g}$ & $2 \mathrm{~g}$ \\
\hline Salt & $1 \mathrm{~g}$ & $1 \mathrm{~g}$ & $1 \mathrm{~g}$ \\
\hline Water & $14 \mathrm{ml}$ & $19 \mathrm{ml}$ & $23 \mathrm{ml}$ \\
\hline
\end{tabular}

PC: $100 \%$ wheat flour.

PS1: $93 \%$ wheat flour $+7 \%$ Tomato pomace.

PS2: $88 \%$ wheat flour $+12 \%$ Tomato pomace.

\section{Sensorial properties}

Were carried out by a properly well trained panel of 15 panelists. They were selected if their individual scores in 10 different tests showed a reproducibility of $90 \%$. The 15 member internal panel evaluated on a three point hedonic scale, scoring was based on a 100 point scale (10-100) where $(90-100)=$ excellent, $(70-80)=$ very good, $(50-60)=$ good, $(30-40)=$ fair and $(10-20)=$ poor. Mineral water was used by the panelists to rinse the mouth between samples according to the method described by AACC, (2002).

\section{Analysis:}

\section{Chemical composition:}

Were determined namely, moisture, crude fat, crude protein and ash according to methods of A.O.A.C. (2000). While total carbohydrate was 
estimated by difference as follows:-Carbohydrate $=100-[($ moisture \% $)+$ $($ ash $\%)+($ protein $\%)+($ fat $\%)]$.

Lycopene and Beta carotene: Was extracted from tomato fruits using acetone and petroleum ether and measured calorimetrically using spectrophotometer at wave length of 503 n.m according to the method described by Ranganna (1976).

Ascorbic acid (vitamin C): was determined by titration with 2.6 diclorophenol indophenol blue dye according to the method reported in A.O.A.C. (2000).

\section{Rheological characteristics}

The effect of fruits and vegetables fiber on the mixing profile of the dough was studied using:

Farinograph: (Brabender, Duisburg, Germany) according to the standard AACC (2000). Farinograph test was carried out to determine the water absorption, arrival time, dough development time, dough stability and degree of weakening.

Extensograph: (Brabender, Duisburg, Germany) according to the standard AACC (2000). Extensograph test was carried out to determine the elastic properties, resistance to extension (B.U.), extensibility (mm), proportional number and energy $(\mathrm{cm} 2)$.

Amylography: The gelatinization and retro gradation behavior of wheat flour were studied using Micro Viscoamylograph (Bra bender, Germany) according to the standard AACC (2000). Wheat flour $15.0 \mathrm{~g}$ was mixed with $0.8 \mathrm{~g}$ of selected hydrocolloid in $100 \mathrm{ml}$ of distilled water. The mixture was heated from $30 \mathrm{oC}$ to $950 \mathrm{C}$ with a constant heating rate of $1.5 \mathrm{oC} / \mathrm{min}$. and held at $95 \mathrm{oC}$ for $30 \mathrm{~min}$. The paste was cooled to $50 \mathrm{oC}$ with the same rate and finally kept at $50 \mathrm{o} \mathrm{C}$ for $10 \mathrm{~min}$. The resulting behavior was studied for the following parameters: gelatinization temperature, peak viscosity, breakdown during heating, heating stability, set back during cooling and cooling stability. All measurements were carried out in triplicate. 


\section{Effect of using tomato pomace powder as a By-product from food factories}

\section{Physical Characteristics for pizza sample}

$\mathrm{PH}$ of dough: was determined by direct immersion of a $\mathrm{pH}$ electrode the batter at room temperature $\left(25^{\circ} \mathrm{C}\right)$ using a Digital $\mathrm{pH}$ meter (Jenway, Model 3020, Dunmow, Essex, UK) Khalil, (1998).

Texture profile analysis of pizza: was determined for product by a universal testing machine (cometech, B type, Taiwan).Provided with software. An aluminum $25 \mathrm{~mm}$ diameter cylindrical probe was used in a "Texture Profile Analysis" (TPA) double compression test to penetrate to $50 \%$ depth, at $1 \mathrm{~mm} / \mathrm{s}$ speed test Bourne, (2003).

\section{Bacteriological examination}

Total bacterial counts (T.B.C) were performed for pizza in Microbiology Dep. Faculty of Agriculture, Mansoura University according to Difico- Manual (1985).

Total bacterial count medium: the nutrient agar medium was used for enumeration of the total bacterial count in pizza.

Constituent of medium was as the follows according to Difico Manual, (1985):-

$\begin{array}{ll}\text { Nutrient agar medium } & (9 \mathrm{l}-1) \\ \text { Beef extract } & 3 \mathrm{gm} . \\ \text { Peptone } & 5.0 \mathrm{gm} . \\ \text { Agar } & 20 \mathrm{gm} . \\ \text { Distilled water } & 1000 \mathrm{ml} \\ \text { PH } & 7.2\end{array}$

\section{Total fungi counts by Martin medium}

Fungal counts were determined by the dilution method on Martins, (1950) medium after 5 days incubation at 30c.

\section{Method of analysis}

Enumeration of pizza microorganism's Serial decimal dilution were prepared prior to making these dilutions, the suspension was shaken mechanically for $15 \mathrm{~min}$ for plate counts, and three plates were prepared from each dilution. 
$\overline{\underline{ }}$

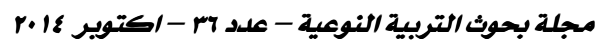

Martins medium Martin, (1950) for fungi:-

Dextrose 10.0 gm., Peptone 5.0 g, Potassium dehydrogenate phosphate $1.0 \mathrm{~g}$, Magnesium sulfate (Mg so $4.7 \mathrm{H} 2 \mathrm{o}$ ) $0.5 \mathrm{~g}$, Rose Bengal 1 part in 30.000 parts of medium, Nutrient agar $20 \mathrm{~g}$, Distilled water $1000 \mathrm{ml}$. the antibiotic was sterilized separately and added aseptically to the sterilized medium(Streptomycin solution $30 \mathrm{ml}$ per 100 cooled medium) for bacteria.

\section{Enumeration of raw material}

Serial decimal dilution were prepared prior to making these dilutions ,the suspension was snake mechanically for $15 \mathrm{~min}$.for plate counts, three plates were prepared from each dilution.

\section{Plate count determinations}

Plate count technique was used to determine total microbial density. For total bacterial colony count determination was employed, triplicate plates were prepared for each dilution and incubated 3 days at $30^{\circ} \mathrm{C}$.

\section{Statistical analysis}

Values represented are the means and standard error, significance was used at P. <0.05. (ANOVA) was done using SPSS (2007) program for windows.

\section{Results and Discussion}

\section{Sensory evaluation}

Table (2) represent sensory properties mean scores of pizza containing tomato pomace powder at two levels of replacement. From this table it could be noticed that pizza made by $93 \%$ Wheat flour $+7 \%$ Tomato pomace powder replacement was high in some parameters tested (taste, color and overall acceptability) with total score of 44.70 compared with control, being less when compared with pizza $88 \%$ Wheat flour $+12 \%$ Tomato pomace powder 48.00 but was still acceptable, (sample rated very good to explanted for different parameters). From the results in the same table it could be noticed that pizza which made with 7 and $12 \%$ tomato pomace replacement gave more or similar less scores when compared with control with total score $43.60,44.70 \%$ and $48.00 \%$, respectively). 


\section{— Effect of using tomato pomace powder as a By-product from food factories}

Montesano et al., (2002) reported that, when samples covered with the toppings of pizza (sauce and cheese), the consumers could not detect a difference in the crust made with high gluten flour.

Table (2): Sensory evaluation of control compared to experimental samples of pizza.

\begin{tabular}{||c||c||c|c||c||c||c||}
\hline Samples & $\begin{array}{c}\text { Texture } \\
(10)\end{array}$ & $\begin{array}{c}\text { Aroma } \\
(10)\end{array}$ & $\begin{array}{c}\text { Taste } \\
(10)\end{array}$ & $\begin{array}{c}\text { Color } \\
(10)\end{array}$ & $\begin{array}{c}\text { Overall } \\
\text { acceptability (10) }\end{array}$ & Total score \\
\hline \hline PC & $\begin{array}{c}8.90 \\
\pm 0.08\end{array}$ & $\begin{array}{c}9.30 \\
\pm 0.07\end{array}$ & $\begin{array}{c}9.10 \\
\pm 0.07\end{array}$ & $\begin{array}{c}7.20 \\
\pm 0.09\end{array}$ & $\begin{array}{c}9.10 \\
\pm 0.04\end{array}$ & $\begin{array}{c}43.60 \\
\pm 0.76\end{array}$ \\
\hline \hline \multirow{2}{*}{ PS1 } & \begin{tabular}{c|c}
8.80 \\
\pm 0.13
\end{tabular} & $\begin{array}{c}9.20 \\
\pm 0.40\end{array}$ & $\begin{array}{c}9.40 \\
\pm 0.13\end{array}$ & $\begin{array}{c}8.10 \\
\pm 0.30\end{array}$ & $\begin{array}{c}9.20 \\
\pm 0.13\end{array}$ & $\begin{array}{c}44.70 \\
\pm 0.43\end{array}$ \\
\hline \hline \multirow{2}{*}{ PS2 } & 9.50 & 9.90 & 9.00 & 9.80 & $9.80 *$ & 48.00 \\
& \pm 0.30 & \pm 0.03 & \pm 0.15 & \pm 0.08 & \pm 0.13 & \pm 0.93 \\
\hline
\end{tabular}

Means in the same raw with different letters are significantly different $(\mathrm{P}<0.05)$.

PC: pizza control 100\% wheat flour. PS1: pizza sample1: $93 \%$ wheat flour $+7 \%$ Tomato pomace. PS2: pizza sample2: $88 \%$ wheat flour $+12 \%$ Tomato pomace.

\section{Chemical composition of TPP and wheat flour}

Data in Table (3) represent the proximate chemical composition of wheat flour (72\% extra) of protein, fat, ash, crude fiber, total carbohydrates contents (on dry weight basis) and moisture contents. From these results the wheat flour was suitable for used to make pizza. Also, this data show the chemical composition of tomato pomace powder on dry weight basis. It could be noticed that the tomato pomace powder was rich in protein, lycopene, dietary fiber and vitamin c. The moisture content of tomato pomace powder was $7.53 \pm 0.04 \%$. Meanwhile, the protein content was $18.70 \pm 0.48 \%$, the fat content $0.43 \pm 0.02 \%$, dietary fiber content $26.87 \pm 0.64 \%$, ash content $5.62 \pm 0.11 \%$, lycopene $9.16 \pm 0.11 \mathrm{mg} / 100 \mathrm{~g}$, Vitamin C $44.6 \pm 0.11 \mathrm{mg} / 100 \mathrm{~g}$ and total Carbohydrate content $67.72 \%$, respectively. In this respect, Harb (1986) determined the chemical 
مجلة بحوث التريية النوعية - علد 7r - مكتوير \&.1

composition of tomato pomace and found that moisture, crude protein and crude fiber content were $9.25,21.5$ and $39.8 \%$, respectively. This finding may focus the interest of utilizing tomato pomace as a high protein source, dietary fiber and Vitamin $\mathrm{C}$ in some food formulation. Generally, the value of protein content was lower than that reported by King and Zeidler (2004) found that protein content was $26.8 \%$, dietary fiber content was $26.3 \%$, and moisture was $5.1 \%$ and fat was $11.9 \%$ in tomato pomace powder. Maheri-Sis et al., (2012) found that chemical composition of tomato pomace on dry matter basis (\%) for dry matter was $94.46 \%$, crude protein was $r \varepsilon_{.} \cdot \wedge \%$, ether extract was $13.98 \%$, crude ash was $0 . v \% \%$, acid detergent fiber was $33.6 \%$, neutral detergent fiber was $47.8 \%$ and non-fiber carbohydrate was $\wedge . \leqslant 1$ and content of lycopene was disagree with Rezaeipour et al., (2012) they reported that lycopene in dried tomato pomace was $0.527 \%$. This result agrees with Abdollahzadeh et al., (2010) they found that dried tomato pomace contains $20.8-23.5 \%$ fiber.

Table (3): Chemical composition of raw material used in making pizza formulae (on dry weight basis).

\begin{tabular}{||l||c|c||}
\hline \hline \multicolumn{1}{|c||}{ Raw Materials } & WF & TPP \\
\hline \hline Moisture \% & $11.93 \pm 0.02$ & $7.53 \pm 0.04$ \\
\hline \hline Protein \% & $10.49 \pm 0.12$ & $18.70 \pm 0.48$ \\
\hline Fat \% & $1.58 \pm 0.15$ & $0.43 \pm 0.02$ \\
\hline \hline *Carbohydrate \% & 74.72 & 67.72 \\
\hline \hline Ash \% & $0.74 \pm 0.08$ & $5.62 \pm 0.11$ \\
\hline \hline DF \% & $0.54 \pm 0.02$ & $26.87 \pm 0.64$ \\
\hline Lycopene $(\mathrm{mg} / 100 \mathrm{~g})$ & $\mathrm{ND}$ & $9.16 \pm 0.11$ \\
\hline \hline Vitamin c $(\mathrm{mg} / 100 \mathrm{~g})$ & $\mathrm{ND}$ & $44.6 \pm 0.11$ \\
\hline \hline
\end{tabular}


Significantly different $* \mathrm{P}<0.05)$. $*$ Carbohydrate was calculated by difference.

$\mathrm{WF}=$ Wheat flour $72 \%$ extra. $\mathrm{DF}=$ Dietary fiber. TPP: Tomato pomace powder. $\mathrm{ND}=$ non detectable

\section{Rheological properties}

Rheological properties of wheat flour are significantly influenced by cultivation environment Mikhaylenko et al., (2000). The gelatinization and retro gradation behavior of wheat flour upon adding different percentage of tomato pomace using Visco amylograph are shown in Table(4). Data show that addition tomato pomace was increase Max. Viscosity from 440 to 560 for dough with $7 \%$ tomato pomace Because of forma reduction in starch content and an increase in protein and fiber content of dough when replaced with tomato pomsac powder. The apparent amylose content of flour correlates significantly with peak viscosity, final viscosity, breakdown and setback in RVA Zeng et al., (1997); Yamamori and Quynh, (2000). Symon and Brennan (2004) reported that substitution of 5\% wheat starch with $\beta$ glucan-rich fiber fractions from barley decreased the peak viscosity, breakdown and final viscosity in comparison to the control starch $(\mathrm{p}<0.05)$. This reduction is likely to be because of water being withheld from the starch granules by the $\beta$-glucan and a decrease in the starch content of wheat flour pastes. Sogi et al., (2002) reported on pasting properties of wheat flour blended with dried tomato seed meal at 0-30\% using Bra bender Visco Amylograph indicated that peak viscosity, viscosity at $95^{\circ} \mathrm{C}$, viscosity at $50^{\circ} \mathrm{C}$ and setback on cooling decreased with the increase in levels of dried tomato seed meal. Sogi et al., (2002) reported that substitution of wheat flour with dried tomato seed meal decreasing in peak viscosity and setback on cooling using Visco amylograph. Conclusion: Addition of any kind of fiber material with high antioxidant like tomato pomace powder activity showed a decrease in viscosity with little modification in baking process, the tomato pomace enriched dough can be used as a functional ingredient. 
Table (4): Rheological characteristics of Visco Amylograph for dough samples compared to control.

\begin{tabular}{||c|l|l|l|l|l|l||}
\hline Sest results & $\begin{array}{l}\text { Transient } \\
\text { Point }{ }^{\circ} \mathrm{C}\end{array}$ & $\begin{array}{l}\text { Max. } \\
\text { Viscosity } \\
\text { B.U }\end{array}$ & $\begin{array}{l}\text { Tamp.at } \\
\text { Max. } \\
\text { Viscosity }{ }^{\circ} \mathrm{C}\end{array}$ & $\begin{array}{l}\text { Viscosity at } \\
95^{\circ} \mathrm{C} \text { B.U }\end{array}$ & $\begin{array}{l}\text { Viscosity at } \\
50^{\circ} \mathrm{C} \text { B.U }\end{array}$ & $\begin{array}{l}\text { Setback } \\
\text { B.U }\end{array}$ \\
\hline \hline DC & 63.0 & 440 & 91.5 & 330 & 700 & 260 \\
\hline DS1 & 57.0 & 560 & 94.0 & 480 & 890 & 330 \\
\hline DS2 & 57.0 & 410 & 96.0 & 360 & 580 & 170 \\
\hline
\end{tabular}

B.U: Bra bender unit. DC: Dough control: 100\% Wheat flour.

DS1: Dough sample 1: $93 \%$ Wheat flour $+7 \%$ Tomato pomace powder.

DS2: Dough sample 2: $\mathbf{8 8 \%}$ Wheat flour $+12 \%$ Tomato pomace powder.

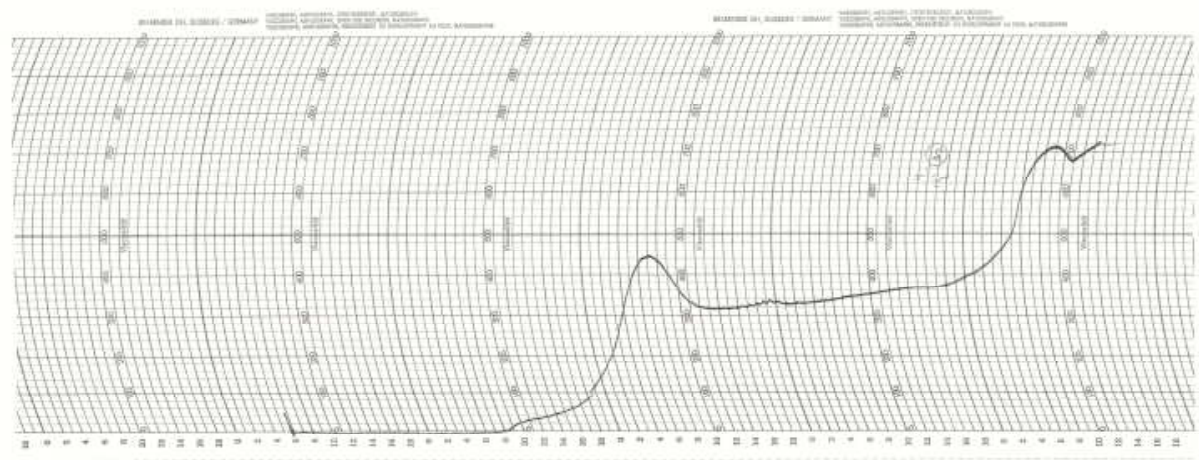

Control (1) WF dough

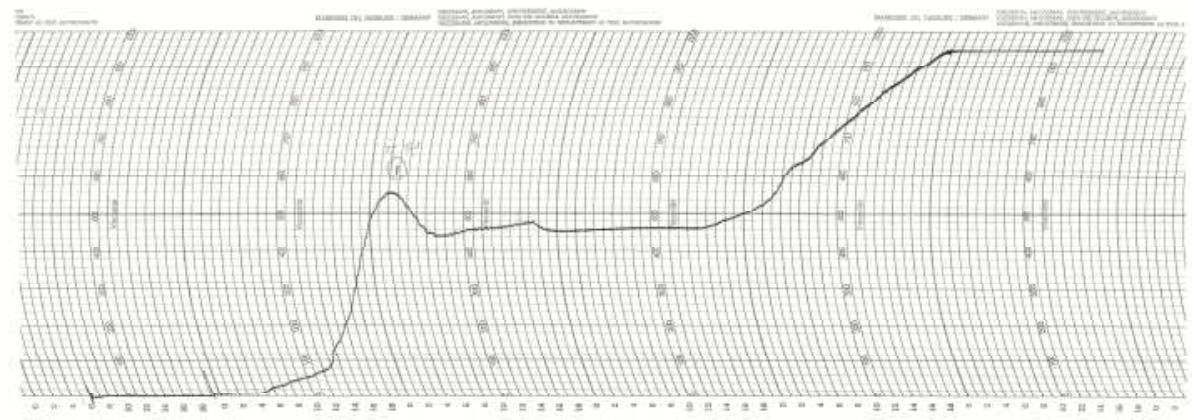

Dough 7\% TPP 


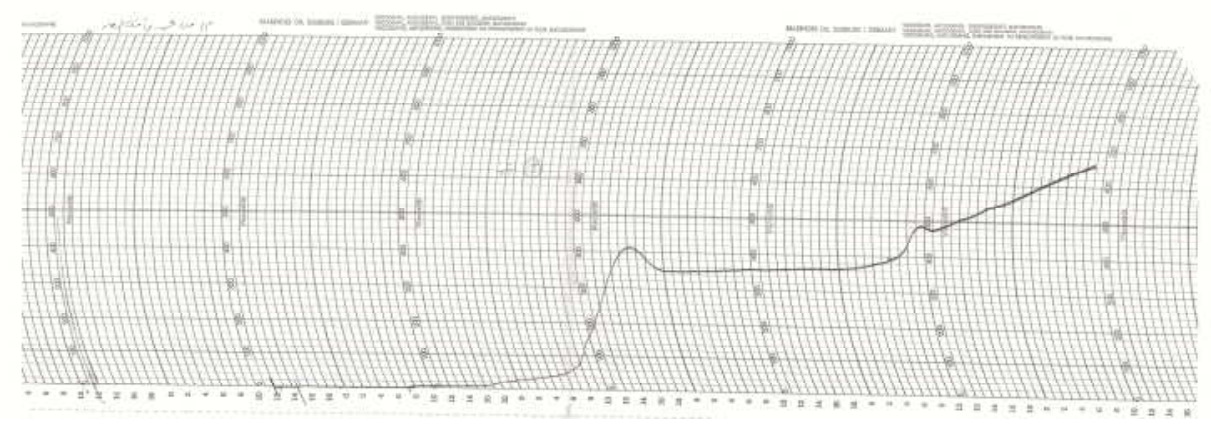

Dough $12 \%$ TPP

Rheological properties (Farinograph parameters) of three different dough formulas $(100 \%$ Wheat flour, $93 \%$ Wheat flour $+7 \%$ Tomato pomace powder and $88 \%$ Wheat flour $+12 \%$ Tomato pomace powder) were studied. The effects of these additions were studied and the obtained data are shown in table (5).Data show that all additions percentage of tomato pomace powder increased the water absorption. Dough stability time is an important index for the strength of the dough. The results show that the addition of $7 \%$ tomato pomace powder and wheat flour\& $12 \%$ tomato pomace powder to wheat flour increased dough stability time $(6.0$ and $5.0 \mathrm{~min})$ than the control wheat flour (2.0min). Tomato pomace powder increased the dough water absorption, reduction in the dough arrival when added to flat breads Majzoobi et al., (2010). Sogi et al., (2002) reported that substitution of wheat flour with dried tomato seed meal (DTSM) effected on rheological properties by increasing in water absorption, dough stability using Farinograph. 
Table (5): Rheological characteristics of Farinograph for different dough formula samples compered to control.

\begin{tabular}{||c|c|c|c|c|c||}
\hline \multirow{2}{*}{$\begin{array}{c}\text { Sest results } \\
\text { Samples }\end{array}$} & $\begin{array}{c}\text { Water } \\
\text { absorption } \\
(\%)\end{array}$ & $\begin{array}{c}\text { Arrival } \\
\text { time } \\
(\mathrm{min})\end{array}$ & $\begin{array}{c}\text { Dough } \\
\text { Development } \\
(\mathrm{min})\end{array}$ & $\begin{array}{c}\text { Dough } \\
\text { stability } \\
(\mathrm{min})\end{array}$ & $\begin{array}{c}\text { Degree of } \\
\text { softening } \\
(\mathrm{B} . \mathrm{U})\end{array}$ \\
\hline \hline DC & 56.0 & 0.5 & 1.0 & 2.0 & 90 \\
\hline DS1 & 59.5 & 0.5 & 1.0 & 6.0 & 90 \\
\hline DS2 & 64.8 & 0.5 & 1.0 & 5.0 & 90 \\
\hline \hline
\end{tabular}

B.U: Bra bender unit. DC: Dough control: 100\% Wheat flour.

DS1: Dough sample 1:93 \% Wheat flour +7\% Tomato pomace powder.

DS2: Dough sample 2:88\% Wheat flour $+12 \%$ Tomato pomace powder.

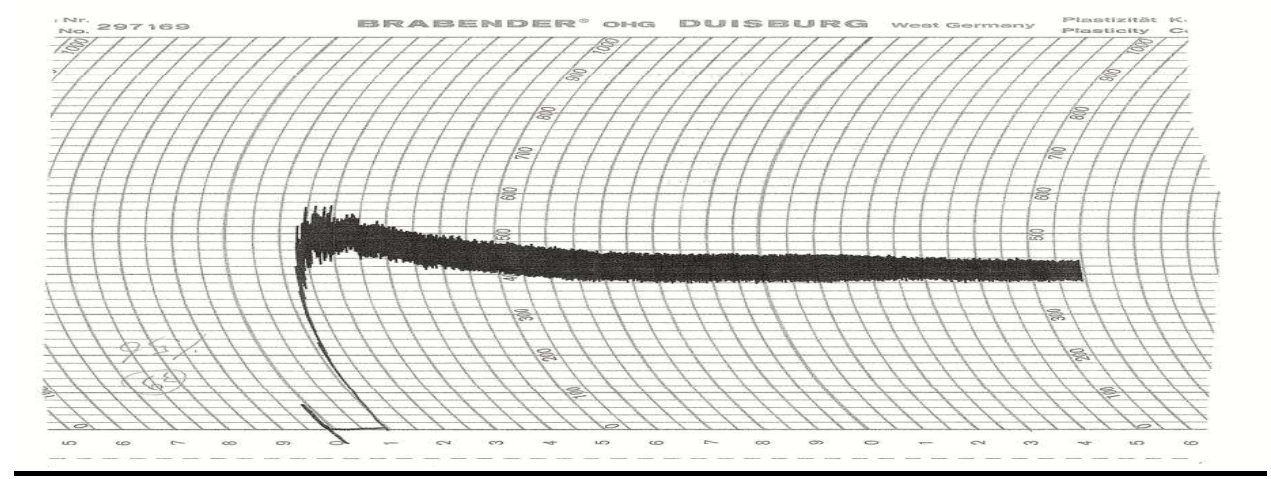

Dough Control100WF 


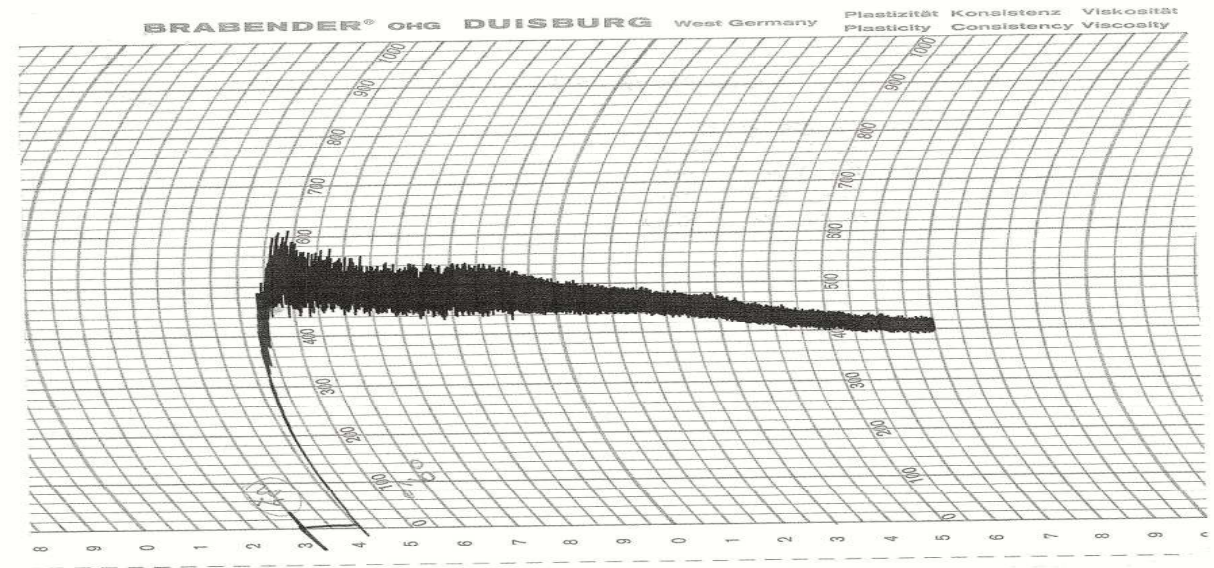

Dough $7 \%$ TPP

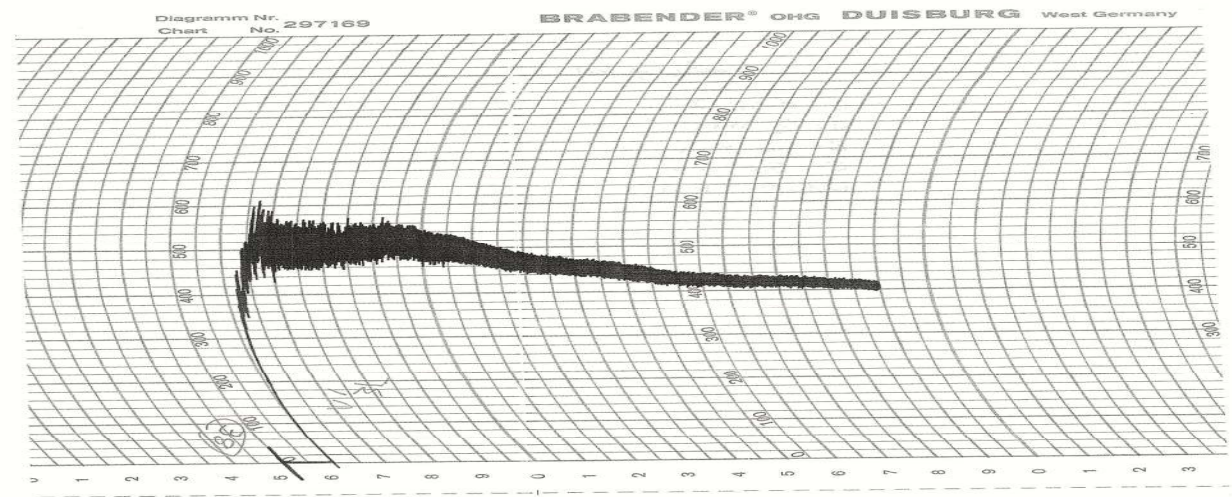

Dough $12 \%$ TPP

Data in Table (6) shows the effect of addition fiber sources (in ratios of 7 and 12\%) with wheat flours (72\% extraction) dough on the Extensograph parameters, elasticity, extensibility, proportional number between them and also the energy. The results show that the elasticity was 310 B.U for the control sample (wheat flour $72 \%$ extract), while it increased with the level $7 \%$ of tomato pomace. Also, the extensibility showed a value of $115 \mathrm{~mm}$ for the control sample (wheat flour $72 \%$ extract) .and decreased with increasing the levels of tomato pomace. Sharoba et al., (2013) they found that blending with fiber sources showed a slight decrease due to the dried fiber sources. The lowest extensibility 
value was recorded due to the blend containing $12 \%$ tomato pomace powder. It could be noted that addition of fiber percentages had a good Extensograph parameters like the control sample increased elasticity and this result agree with those obtained by Doweidar (2001) who found that the addition of dietary fiber source led to increase elasticity.

Table (6): Rheological characteristics of Extensograph for dough samples compered to control.

\begin{tabular}{|c||c|c|c|c||}
\hline \multirow{2}{*}{ Test results } & \multicolumn{4}{|c|}{ Extensograph } \\
\cline { 2 - 5 } Samples & $\begin{array}{c}\text { Elasticity } \\
(\text { B.U) }\end{array}$ & $\begin{array}{c}\text { Extensibility } \\
(\mathrm{mm})\end{array}$ & P.N & Energy (cm2) \\
\hline \hline DC & 310 & 115 & 2.70 & 61 \\
\hline DS1 & 480 & 80 & 6.00 & 60 \\
\hline DS2 & 400 & 75 & 5.33 & 53 \\
\hline
\end{tabular}

DC: Dough control: 100\% Wheat flour. DS1: Dough sample 1:93 \% Wheat flour $+7 \%$ Tomato pomace powder. DS2: Dough sample 2:88\% Wheat flour $+12 \%$ Tomato pomace powder. PN: proportional number. B.U: Bra bender unit.

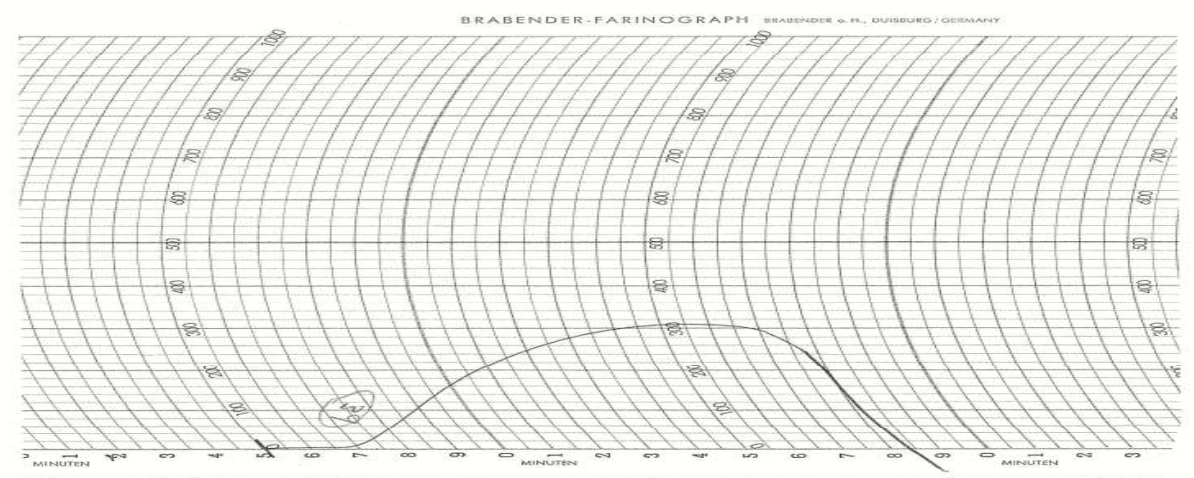

Dough Control100WF 


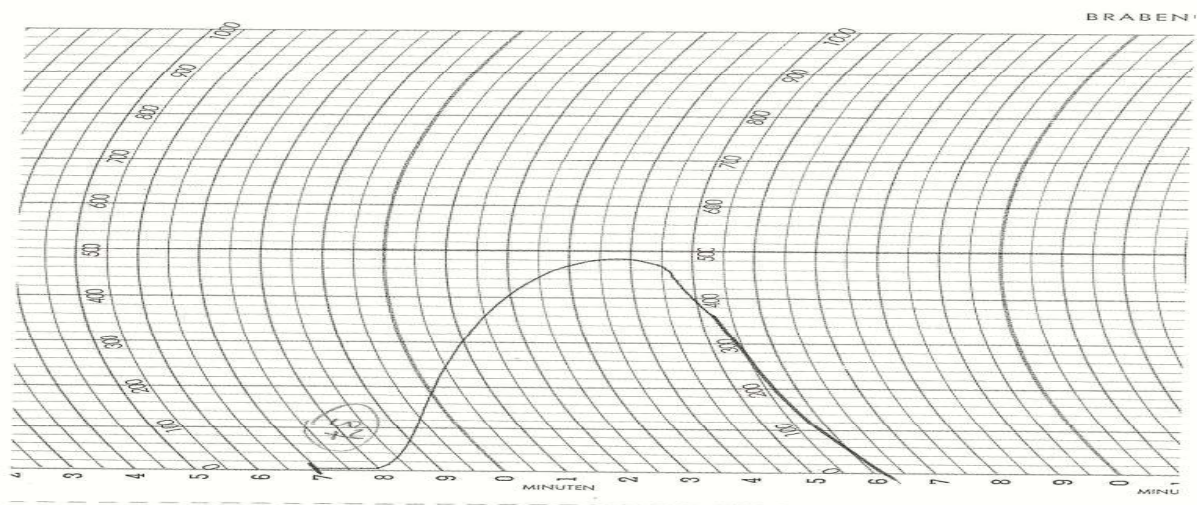

Dough 7\% TPP

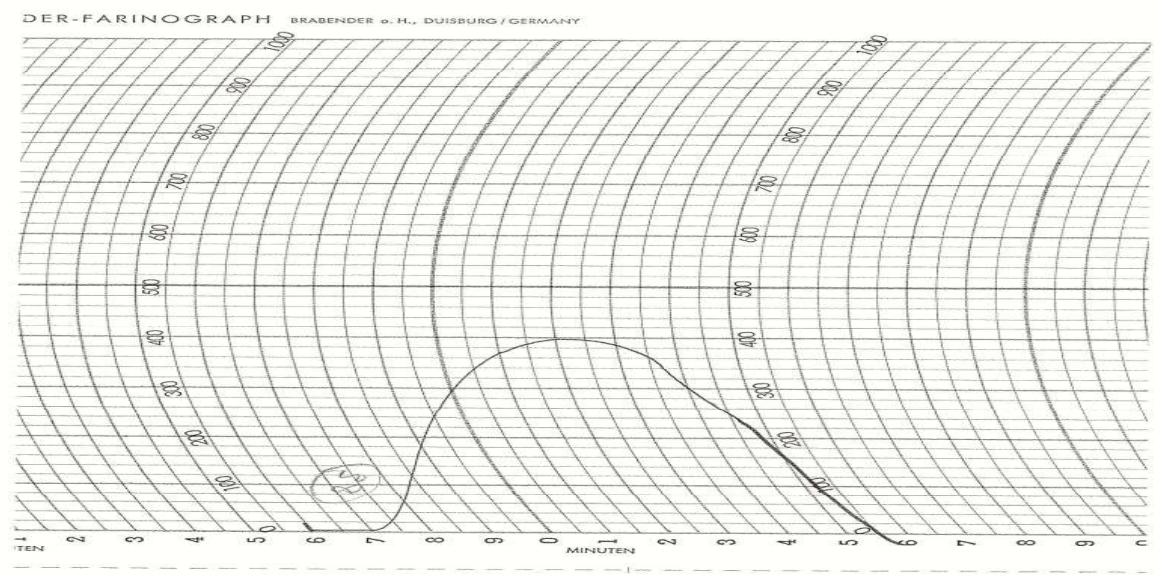

Dough $12 \%$ TPP

\section{Proximate chemical composition of pizza samples}

Data in Table (7) showed the gross chemical composition of pizza formulae processed made from wheat flour (72\%extraction) with substitution with by-products of the food factories namely tomato pomace. Results indicated that moisture content ranged from $(9.89 \pm 0.11 \%$ to $14.76 \pm 0.07 \%$ ) in pizza formulae. The highest content of moisture $(14.76 \pm 0.07 \%)$ recorded for pizza formulae contained $12 \%$ tomato pomace .while pizza control has the lowest content of moisture was $(9.89 \pm 0.11 \%)$. Results also indicated that fat content in prepared pizza samples was $14.12 \pm 0.19 \%$ and $14.99 \pm 0.18 \%$ for pizza formulae contained $7 \%$ tomato 
pomace powder and pizza formulae contained $12 \%$ d tomato pomace powder, respectively, protein content was $13.28 \pm 0.06-15.17 \pm 0.05$ in prepared pizza samples $7 \%$ and $12 \%$, respectively and dietary fiber content was 23.97 $\pm 0.24-25.16 \pm 0.37$ in prepared pizza samples $7 \%$ and $12 \%$, respectively. This result agree with Abdollahzadeh et al., (2010); Aghajanzadeh-Golshani et al., (2010); Mirzaei-Aghsaghali et al., (2011) they found that tomato pomace produced in Iran contains $21.7-26.4 \%$ crude protein, 13.4-15.9\% fat, 3.4-12.2\% crude ash and 49.2-57.4\% neutral detergent fiber on dry matter basis and 26\% dry matter on as-fed basis, Keiko Goto and Stephanie Bianco-Simeral, (2011) they found that fat content in pizza control was $18.0 \%$. Sogi et al., (2002) reported that the bread supplemented with $10 \%$ dried tomato seed meal exhibited good sensory characteristics and improved protein quality. Lycopene, B-carotene and Vitamin $C$ were determined in pizza control, pizza formulae contained $7 \%$ tomato pomace and pizza formulae contained $12 \%$ tomato pomace and recorded in table (7), noted that pizza formulae contained $88 \%$ wheat flour $+\mathbf{1 2 \%}$ tomato pomace is the highest content in Lycopene, Beta carotene and Vitamin $C$ content and it due to tomato pomace powder content in pizza. This result agree with Aghajanzadeh et al., (2010) they reported that this by-product is a good source of vitamin B1, B2 and A. dried tomato pomace (DTP) is an excellent source of $\alpha$-Tocopherol (Vitamin E) and lycopene Sahin et al., (2008). So, it may be a new source of antioxidant to prevent lipid oxidation in broiler meat. on the other hand, other investigators have shown that Vitamin $C$ and Vitamin E improved feed conversion and layer performance Whitehead et al., (1998), Bollenger Lee et al., (1999), Sahin and Kucuk (2001); Sahin et al., (2002). 


\section{—Effect of using tomato pomace powder as a By-product from food factories}

Table (7): Chemical composition for pizza formulae sample compered to control (g. /100g. on dry weight basis).

\begin{tabular}{|c|c|c|c||}
\hline Sarameter & PC & PS1 & PS2 \\
\hline \hline Moisture \% & $9.89 \mathrm{c} \pm 0.11$ & $12.84 \mathrm{~b} \pm 0.12$ & $14.76 \mathrm{a} \pm 0.07$ \\
\hline Protein \% & $10.35 \mathrm{c} \pm 0.03$ & $13.28 \mathrm{~b} \pm 0.06$ & $15.17 \mathrm{a} \pm 0.05$ \\
\hline Fat \% & $14.01 \mathrm{~b} \pm 0.06$ & $14.12 \mathrm{~b} \pm 0.19$ & $14.99 \mathrm{a} \pm 0.18$ \\
\hline *Carbohydrate\% & 63.35 & 55.91 & 50.84 \\
\hline Ash \% & $2.40 \mathrm{c} \pm 0.03$ & $3.85 \mathrm{~b} \pm 0.06$ & $4.24 \mathrm{a} \pm 0.03$ \\
\hline Dietary fiber \% & $0.25 \mathrm{c} \pm 0.02$ & $23.97 \mathrm{~b} \pm 0.24$ & $25.16 \mathrm{a} \pm 0.37$ \\
\hline Lycopene (mg/100g) & $\mathrm{ND}$ & $1.18 \mathrm{~b} \pm 0.02$ & $3.95 \mathrm{a} \pm 0.13$ \\
\hline $\begin{array}{c}\text { Beta } \\
\text { carotene(mg/100g) }\end{array}$ & $\mathrm{ND}$ & $2.01 \mathrm{~b} \pm 0.08$ & $3.97 \mathrm{a} \pm 0.06$ \\
\hline \begin{tabular}{c} 
V.C $(\mathrm{mg} / 100 \mathrm{~g})$ \\
\hline
\end{tabular} & $0.25 \pm 0.23$ & $12.31 \mathrm{~b} \pm 0.14$ & $18.62 \mathrm{a} \pm 0.46$ \\
\hline
\end{tabular}

Significantly different $(P<0.05) . \quad *$ Carbohydrate was calculated by difference. PC: Pizza control: 100\% wheat flour. PS1: Pizza sample1: 93\% wheat flour +7\%Tomato pomace.

PS 2: Pizza sample2: $88 \%$ wheat flour $+12 \%$ Tomato pomace. $\mathrm{ND}=$ non detectable.

\section{Physical Characteristics for pizza sample}

Data of $\mathrm{pH}$ value, firmness are represented in Table (8). The results showed that replacing wheat flour with tomato pomace powder (7 and 12\%) did not have any significant $(\mathrm{P} \leq 0.05)$ effect on batter $\mathrm{PH}$. All $\mathrm{PH}$ value were weakly Acidity, ranging from $\mathrm{PH}$ 5.57: 5.64.From this result it noted that addition of tomato pomace powder decreased $\mathrm{pH}$ value compared with pizza control but high percentage of tomato pomace powder increasing $\mathrm{pH}$ value and this result agree with Yuangklang et al., (2010) they found that increasing intakes of tomato pomace powder caused increasing $\mathrm{PH}$ values. 
Chumpawadee and Pimpa (2009) concluded that these results are due to high carbohydrate fraction in tomato pomace. The results presented in Table (8) show the texture characteristics of pizzas contained different percentage of fiber source. Firmness must be explained by the different chemical interactions. Dietary fiber sources led to the hardest with firmness higher than that of the control Gomez et al., (2007).

Table (8): $\mathrm{pH}$ of dough and texture profile analysis of pizza samples compared to control.

\begin{tabular}{|c|c|c|}
\hline Samples & $\mathrm{pH}$ & Firmness \\
\hline \hline PC & $5.64^{*} \pm 0.18$ & $65.46^{\mathrm{c}} \pm 0.09$ \\
\hline PS1 & $5.57 \pm 0.24$ & $88.07^{\mathrm{b}} \pm 0.32$ \\
\hline PS 2 & $5.60 \pm 0.09$ & $91.06^{\mathrm{a}} \pm 0.93$ \\
\hline
\end{tabular}

* The mean difference is significant at the 0.05 level. PC: Pizza control: $100 \%$ wheat flour.

PS1: Pizza sample1: 93\% wheat flour + 7\%Tomato pomace.

PS 2: Pizza sample2: $88 \%$ wheat flour + 12\%Tomato pomace.

\section{Bacteriological Examination}

Data presented in table (9) showed the average of total bacterial count and total fungi count of pizza formulae at zero time and three days. It is clear from these results that total bacterial count of samples with $\mathbf{7 \%}$ and $\mathbf{1 2 \%}$ tomato pomace was less than total bacterial count of pizza control and this result due to Tomato Pomace is a by-product in the Tomato processing industry is capable of synthesizing Silver Nanoparticle. It showed good antibacterial activity towards resistant pathogens. Moreover, the process for the production of Silver Nanoparticle is environmental friendly and free from organic solvents and toxic chemicals. So, it is one of the effective recycling processes to utilize the tomato pomace. Josephine Nirmala Many et al., (2014). Also, the international 


\section{- Effect of using tomato pomace powder as a By-product from food factories}

Microbiological standard recommended that the limit of bacterial contaminate for food of less than $10^{6} \mathrm{cfu} / \mathrm{g}$. Anon (1974), whereas Rombouts and Nouts (1995) revealed that bacterial counts obtained in plants food were in the order of $12 \times 10^{7}$ to $108 \mathrm{cfu} / \mathrm{g}$.

Table (9): Total bacterial count and total fungi count of pizza samples compered to control.

\begin{tabular}{|c|c|c|c||}
\hline \multirow{2}{*}{ Samples } & \multicolumn{3}{|c||}{ At zero time } \\
\cline { 2 - 4 } & $c f u / m l$ & log/cfu/ml & Fungi \\
\hline \hline PC & $220 \times 10^{2}$ & 4.34 & $183.50 \times 10^{2}$ \\
\hline PS1 & $185.55 \times 10^{2}$ & 4.27 & $171.52 \times 10^{2}$ \\
\hline Ps2 & $170.30 \times 10^{2}$ & 4.23 & $161.30 \times 10^{2}$ \\
\hline \multicolumn{4}{|c||}{ After three days } \\
\hline Samples & $c f u / m l$ & log/cfu/ml & Fungi \\
\hline PC & $39.50 \times 10^{2}$ & 3.59 & $4.00 \times 10^{2}$ \\
\hline PS1 & $36.00 \times 10^{2}$ & 3.56 & $2.33 \times 10^{2}$ \\
\hline PS2 & $33.00 \times 10^{2}$ & 3.52 & $1.24 \times 10^{2}$ \\
\hline
\end{tabular}

PC: Pizza control: $100 \%$ wheat flour.

PS1: Pizza sample1: 93\% wheat flour + 7\%Tomato pomace.

PS 2: Pizza sample2: $88 \%$ wheat flour $+12 \%$ Tomato pomace.

\section{Reference:}

A.A.C.C., (2000): Approved methods of American Association of Cereal Chemists (10th Ed.).Published by American Association of Cereal Chemists, Ins. Saint Paul and Minnesota. USA.

A.O.A.C. (2000): Official Methods of Analysis (17thed.). Arlington, VA: Association of Official Analytical Chemists, AOAC International.

Abdollahzadeh F, Pirmohammadi R, Fatehi F and Bernousi I. (2010): Effect of feeding ensiled mixed tomato and apple pomace on performance of Holstein dairy cows. Slovak J. Anim. Sci., 43(1): 31-35.

Aghajanzadeh-Golshani A, Maheri-Sis N, Mirzaei-Aghsaghali $A$ and Baradaran-Hasanzadeh AR. (2010): Comparison of nutritional 
value of tomato pomace and brewers grain for ruminants using in vitro gas production technique. Asian J. Anim. Vet. Adv., 5(1): 43-51.

Anonymous (1974): Biological Specification for Food -Principles and Specific Applications, University of Toronto Press, Canada.

Assi J.A. and King AJ (2007): Assessment of selected antioxidants in tomato pomace subsequent to treatment with the edible oyster mushroom, pleurotus ostreatus, under solid-state fermentation. J Agric Food Chem 55: 9095-9098.

Bollenger-Lee,S., P.E.V. Williams and C.C. Whitehead, (1999): Optimal dietary concentration of vitamin $\mathrm{E}$ for alleviating effect of heat stress on egg production in laying hens. Br. Poult. Sci., 40: 102-7.

Bourne, M. C. (2003): Food texture and viscosity: Concept and mea surement. Elsevier Press, New York/ London.

Carlson, B.L.; Knorr, D., and Watkins, T.R. (1981): Influence of tomato seed addition on the quality of wheat flour breads. J. Food Sci. 46:1029$31,1042$.

Chumpawadee S. (2009): Degradation characteristics of tomato pomace, soybean hull and peanut pod in the rumen using nylon bag technique. Pak. J. Nutr., 8(11): 1717-1721.

Clarke, C. H., and Farrell, G. (2000): The effects of recipe formulation on the textural characteristics of microwave-reheated pizza bases. Journal of the Science of Food and Agriculture, 80, 1237-1244.

Difico-Manual (1985): Dehydrated culture media and reagents for Microbiology .tenth Edition, Detroit, Michigan, 48232.USA. Page 619.

Dotas D.; Zamanidis S. and Balios J. (1999): Effects of dried tomato pomace on the performance and egg traits of laying hens. Br Poult Sci. 40: 695-697.

Doweidar, M. M.., (2001): Chemical and physical studies on some natural resources used in improving bakery products. Ph.D. Thesis Fac. of Agric. Cairo Univ., Egypt. 


\section{Effect of using tomato pomace powder as a By-product from food factories}

Gomez, M.; Ronda, F.; Coballera, A.P.; Blanco, A.C.and Rosell, C.M. (2007): Functionality of different hydrocolloids on the quality and shelf life of yellow layer cakes. Food Hydrocolloids, 21(2), 167-173.

Goto, K. and Bianco-Simeral, S. (2011): Acceptance of a Healthier Substitute for Regular Pepperoni Pizza among Campus Consumers .Californian Journal of Health Promotion, Volume 9, Issue 1, 09-17 California State University, Chico.

Haddadin MSY, Abu-Reesh IM, Haddadin FAS and Robinson, R.K. (2001): Utilization of tomato pomace as a substrate for the production of vitamin B12 - a preliminary appraisal. Bio resource Tech 78: 225-230.

Harb,M., (1986): Fattening of Awassi male lambs using tomato pomace. Dirasat, 13: $51-71$.

Hegazy, A.L. and Ibrahium, M.I. (2009): Evaluation of the Nutritional Protein Quality of wheat Biscuit Supplemented by Fenugreek seed Flour, Department of Food Science and Technology, Faculty of Agriculture, Al Azhar Uni., Cairo, Egypt.

Josephine Nirmala Many, B. Radhika and Ganesan T. (2014): SYNTHESIS OF SILVER NANOPARTICLE USING FRESH TOMATO POMACE EXTRACT. International Journal of Nano materials and Bio structures; 4(1): 12-15.

Khalil, A.H. (1998): The influence of carbohydrate-based fat replacers with and without emulsifier on the quality characteristics of low-fat cake. Plant Foods for Human Nutrition 52: 299-313.

King A.J. and Zeidler G. (2004): Tomato Pomace May be a Good Source of Vitamin E in Broiler Diets. California Agric. 58:1

Lone T.A.; Pence D.; Levi A.E.; Chan K.K. and Bianco-Simeral S. (2009): Marketing healthy food to the least interested consumers. Journal of Foodservice, 20(2), 90-99.

Majzoobi, M., Ghavi, F., Farahnaky, A., Jamalian, J., and Mesbahi, G. (2010): Effect of tomato pomace powder on the physicoc hemical 
properties of flat bread (barbari bread). J. Food Proc. Pres., 35: 247-256.

Martin, J.P. (1950): use of acid, rose Bengal and streptomycin in the plate method for estimating soil fungi. Soil sci.69:215.

Mikhaylenko, G.G., Czuchajowska, Z., Baik, B.K. and Kidwell, K.K., (2000): Environmental influence on flour composition, dough rheology and baking quality of spring wheat. Cereal Chemistry, 77(4):507$511,2000$.

Mirzaei-Aghsaghali A, Maheri-Sis N, Mansouri H, Razeghi ME, Safaei AR, Aghajanzadeh-Golshani A and Alipor K. (2011): Estimation of the nutritive value of tomato pomace for ruminant using in vitro gas production technique. Afr. J. Bio technol., 10(33): 6251-6256.

Montesano, M., Duffrin, M.W. and Heidal, .K. (2006): Consumer acceptance of pizza and pizza crust made with whole wheat flour and added flaxseed. Journal of the American Dietetic Association 106(8).

Montesano, M., M. W. Duffrin and K. Heidal. (2002): Consumer acceptance of pizza and pizza crust made with whole wheat flour and added flaxseed. Journal of the American Dietetic Association, A-55. Nutr., 69: 395 . 402.

Maheri-Sis Naser; Mehdi Eghbali-Vaighan,Ali Mirzaaghazadeh and Yahya Ebrahimnezhad (2012): Effect of microwave irradiation on the fermentation characteristics and nutritive value of tomato pomace for ruminants using in vitrogas production technique. J. BioSci. Biotech. 1(3): 261-266.

Ranganna, S. (1976): In Manual of Analysis of Fruits and Vegetable Products. Mc Graw Hill New Delhi p.77.

Rezaeipour V., Dastar B., Boldaji F., Yaghobfar A. and Gheisari A. A.(2012): Effects of Dietary Dried Tomato Pomace with an Exogenous Enzyme Supplementation on Growth Performance, Meat Oxidative Stability and Nutrient Digestibility of Broiler Chickens. 
Journal of Animal Science Advances. J. Anim. Sci. Adv., 2012, 2(9):777-786.

Rombouts, F.M. and Nouts, M.J.R. (1995): Microbial Fermentation in the Production of plant food, J. Appl. Bacterial. , 79. 1085-1175.

Sahin N, Orhan C, Tuzco M, Sahin K. and Kocuk O. (2008): The effects of tomato powder supplementation on performance and lipid peroxidation in quail. Poultry Sci. 87: 276-283.

Sahin, K., O. Kucuk, N. Sahin and M. Sari, (2002): Effects of vitamin C and vitamin $\mathrm{E}$ on lipid peroxidation status, serum hormone, metabolite, and mineral concentrations of Japanese quails reared under heat stress (34 C). Int. J. Vitam. Nutr. Res., 72: 91-o 100.

Sahin,K. and O. Kucuk,( 2001): Effect of vitamin $C$ and vitamin $E$ on performance, digestion of nutrients and characteristics on Japanese quails reared under chronic heat stress $(34 \mathrm{C})$. J. Animal Physiology/ An Animal Nutr., 85: 335-41.

Sharoba, A.M.; Farrag, M.A. and Abd El-Salam, A.M (2013): Utilization of some fruits and vegetables waste as a source of dietary fiber and its effect on the cake making and its quality attributes. Journal of Agro alimentary Processes and Technologies. 19(4), 429-444.

Sogi, D.S.; Sidhu, J.S.; Arora , M.S.; Garg, S.K.; and Bawa, A.S. (2002): Effect of tomato seed meal supplementation on the dough and bread characteristics of wheat (PBW343) flour. Inter. J. Food Properties. 5: 563-71.

Sonja Djilas Jasna; Čanadanovic; brunet Gordana Ćetkovic (2009): BY PRODUCTS OF FRUITS PROCESSING AS A SOURCE OF PHYTOCHEMICALS. Chemical Industry \& Chemical Engineering Quarterly 15 (4) 191-202.

Spss, (2007): Statistical Package for Social Science program version 17 for windows, SPSS Inc., Chicago. Ib., USA.

Squires M.W.; Naber E.C. and Toelle V.D. (1992): The effects of heat, water, acid and alkali treatment of tomato cannery wastes on growth, 
Meta bolisable energy value and nitrogen utilization of broiler chicks. Poultry Sci. 71: 522-529.

Symons, L.J.; and Brennan, C.S. (2004): The effect of Barley $\beta$-glucan fiber fractions on starch gelatinization and pasting characteristics. J. Food Sci. 69:FCT257-261.

Tribole, E. (1999): Stealth health: How to sneak nutrition painlessly into your diet. 1stEd. New York: Viking. 240p.

Wagner, B., Senauer, B. and Runge, C.F. (2007): An empirical analysis of and policy recommendations to improve the nutritional quality of school meals. Review of Agricultural Economics, 29(4), 672-688.

Whitehead, C.C., S. Bollinger-Lee, M.A. Mitchell and P.E.V.Williams, (1998): Vitamin E can alleviate the depressedegga production of heat stressed laying hens. Br. Polut. Sci., 39: 544-6.

Yamamori, M.; and Quynh, N.T. (2000): Differential effects of Wx-A1, -B1, and -D1 protein deficiencies on apparent amylase content and starch pasting properties in common wheat. Theory Appl. Genet.100: 32-8.

Yuangklang C., K. Vasupen, S. Wongsuthavas, S. Bureenok, P. Panyakaew, A. Alhaidary, H.E. Mohamed and A.C. Beynen(2010): Effect of Replacement of Soybean meal by Dried Tomato Pomace on Rumen Fermentation and Nitrogen Metabolism in Beef Cattle American .Journal of Agricultural and Biological Sciences 5 (3): 256-260, 2010 ISSN 1557-4989 @ 2010 Science Publications.

Zeng, M.; Morris, C.F.; Batey, I.L.; and Wrigley, C.W. (1997): Sources of variation for starch gelatinization, pasting, and gelation properties in wheat. Cereal Chem. 74: 63-71.1. 


\section{تأثيراستخدام مسموق تفل الطماطم كمنتهج ثانوي لهانع الأغذية علي الصفات الصسية والريولوجية و الكيـيائية والميكربيرالوجية لعبينة البيترا \\ عناف هازمحمود رمضاز حـرشا محمد بجيب أحمد و ميمحمد رأفت أحمد الفـار الملخص العربي}

الهدف من هذه الدراسـة استخدام مسحوق تفل الطماطم كمنتج ثانوي لمصانع الاغذيـة يِّ

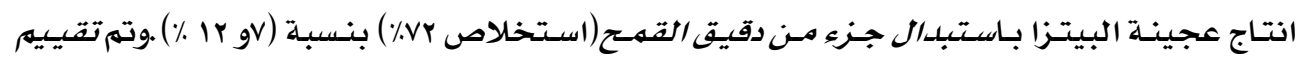

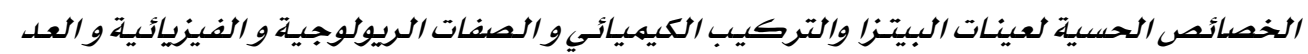

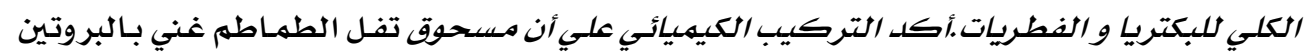

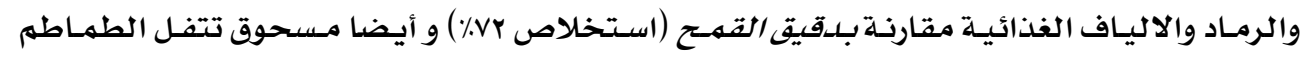

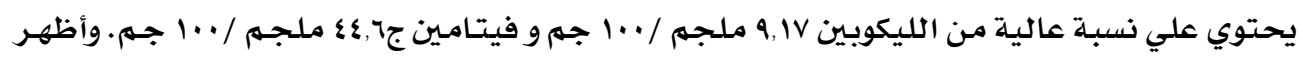

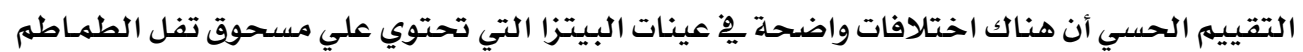

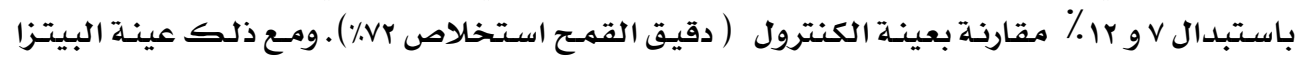

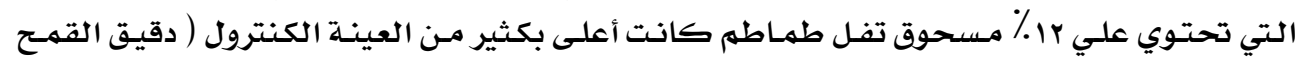

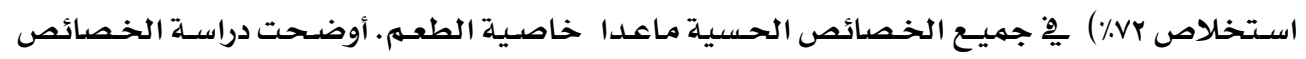

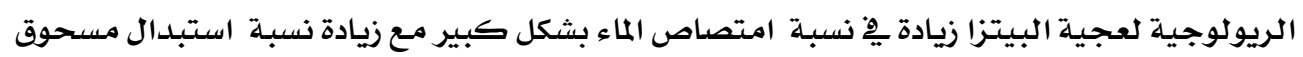

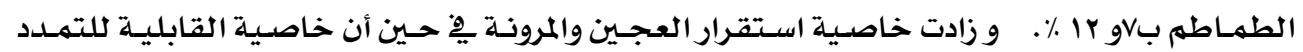

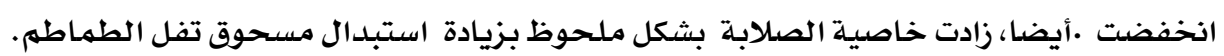

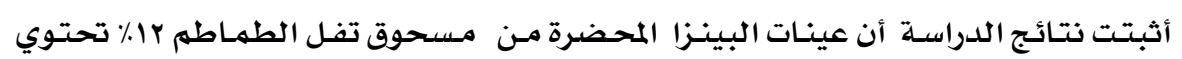

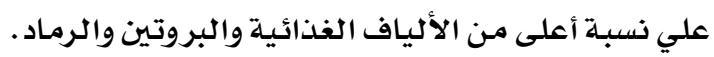

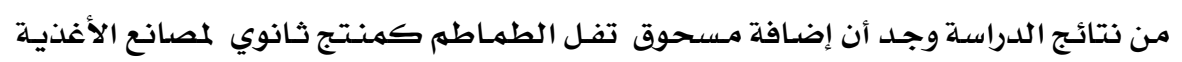
بنسبة تصل إلى r \% كانت ممكنة لإنتاج بيتزا مقبولة حسيا.

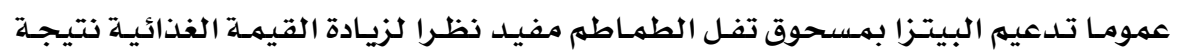

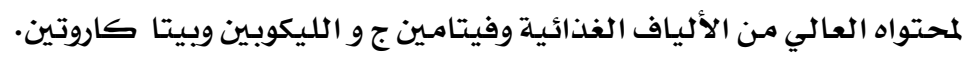

